УДК 159.923.2:364-051

DOI https://doi.org/10.32838/2709-3093/2021.3/04

Казанжи М.Й.

Південноукраїнський національний педагогічний університет імені К.Д. Ушинського

Вдовіченко О.В.

Південноукраїнський національний педагогічний університет імені К.Д. Ушинського

\title{
КРЕАТИВНІСТЬ ТА РЕФЛЕКСІЯ ЯК ОСОБИСТІСНІ МЕХАНІЗМИ ЗБАГАЧЕННЯ ПОТЕНЦІАЛУ САМОЗМІНЮВАННЯ
}

У сучасних умовах життедіяльності, з переважанням невизначеності та постійних трансформацій, соияіально важливою якістю пересічної людини стає ї̈ здатність до змін, швидкого та адекватного реагування на виклики сьогодення, трансформаиія себе, здатність ї̈ здійснювати, щзо привертає увагу науковців до глибшого дослідження самозмінювання особистості. Аналіз наявних робіт з означеної проблематики показав, щуо попри постійний фокус наукового пошуку психологів у проблемному полі різних аспектів самозмінювання, лише обмежена кількість робіт торкається виявлення психологічних механізмів иього процесу, знання про які дозволяє враховувати індивідуальні можливості людини. У зв 'язку з иим досить актуальним завданням є виявлення особистісних механізмів розширення потениіалу самозмінювання, співвідношення яких дає змогу визначати особливості, оцінювати контекст та творчо змінювати себе, виявляючи індивідуальність та ефективність у самозмінюванні.

Задля вирішення ц̧ього завдання було підібрано комплекс психодіагностичних інструментів, до якого ввійшли: Опитувальник «Потенціал самозмінювання» (В.Р. Манукян, І.Р. Муртазіна, Н.В. Грішина), «Методика рівня вираженості та спрямованості рефлексії» (М. Грант) та «Методика діагностики особистісної креативності» (О.Є. Тунік). До вибірки дослідження ввійшло 100 осіб - студенти (оскільки ияя категорія осіб за відомостями літератури схильна до самозмінювання).

За результатами дослідження встановлено, щуо потенціал самозмінювання людини тісно пов'язаний з ї̈ креативністю, а потреба в самозмінюванні викристалізовується через залучення рефлексї, вектору ї̈ спрямованості як на себе, так $і$ на соиіум. Кластерний аналіз показав специфіку взаємозв 'язку самозмінювання, креативності та рефлексї, позначивщи їх підпорядкованість та значущість всіх для певного рівня вираженості потенціалу самозмінювання, щуо демонструє збагачення потенціалу самозмінювання через підвищення рефлексивності та креативності людини. Загалом за результатами дослідження позначено напрями подальшої практичної роботи щодо збагачення потениіалу самозмінювання.

Ключові слова: самозмінювання, потенціал самозмінювання, креативність, рефлексивність, психологічний механізм.

Постановка проблеми. В умовах сучасного суспільства і в аспекті невизначеності «текучої дійсності» на перший план виходить питання змін, трансформації людини, іiі підлаштовування або ж навпаки - дієвий супротив певним впливам. Тож не дивним є все частіше звертання науковців до окреслення поля самозмінювання особистості у контексті його дослідження як динамічної характеристики, змінюваної у кожний момент часу, так і стабільної величини - потенціалу чи відповідного ресурсу; як відповіді на впливи ззовні, так і власні дієві спонукання; як характеристики, що властиві кожній людині, так і специфічної індивідуальної риси тощо. Достеменно зрозумілим $\epsilon$ те, що ця тема актуальною стала не зненацька i $є$ природною реакцією на виклики суспільства щодо затребуваності людей, здатних до швидкого реагування, гнучкості та ефективності як в обранні способу взаємодії зі світом, так і у прийнятті рішення, релевантного конкретним обставинам.

У зв'язку з цим досить актуальним завданням $\epsilon$ виявлення особистісних механізмів розширення потенціалу самозмінювання, співвідношення яких дає змогу визначати особливості, оцінювати контекст та творчо змінювати себе, виявляючи індивідуальність та ефективність у самозмінюванні.

Аналіз останніх досліджень і публікацій. Значний внесок у розробку проблематики самозмінювання внесли В.P. Манукян I.P. Муртазіна, 
Н.В. Грішина, В.М. Косирєв [3; 7; 8; 9] та інші, які не тільки позначили власне трактування самозмінювання, а й узагальнили значний пласт наявної інформації.

T.М. Титаренко зауважує, що «ми поступово стаємо вільнішими у власному життєвому світі, більше прислухаємося до своїх глибинних прагнень, до тієї «вільної гри єства», яку раніше приховували, витісняли й гальмували. У постмодерністському контексті особистість уже не така цілеспрямовано-ригідна, вона більше відкрита експериментуванню, готова ризикнути, помилитися, розпочати все знову» [15, с. 3]. Таким чином, новітні і швидко змінні умови життя вимагають від особистості розвитку певних особливостей, що сприятимуть збагаченню iї потенціалу до самозмін. Своєю чергою це дасть можливості адаптуватися до сучасних умов.

На думку Н.В. Гришиної, поняття потенціалу самозмін особистості включає (1) здатність і готовність людини до усвідомлення «викликів» ситуації і необхідності змін, (2) готовність до прийняття цієї необхідності і (3) готовність діяти відповідно до усвідомлюваних викликів. Визначені складники у сукупності визначають потенціал, що відображає можливості змінювання особистості [3, с. 126]. Відзначимо, що доречним $є$ не тільки обгрунтувати конструкт «потенціалу самозмінювання», його діагностичні кореляти, а також важливо визначити саме особистісні механізми потенціалу самозмінювання.

C.I. Розум у загальному вигляді «психологічний механізм» розуміє як процес, що забезпечує перетворення, яке сприймається суб'єктом як об'єктивної реальності, так і професійної діяльності в його внутрішній зміст [14]. Під час дослідження саме психологічних механізмів самозмінювання, які задіяні в навчальній діяльності в студентському віці, В.М. Косирєвим було представлено цикл самозмінювання, що передбачає актуалізацію на кожному з етапів певних психологічних механізмів, останнім етапом, власне, $\epsilon$ самоздійснення [7, с. 84].

В аспекті вивчення особистісних механізмів потенціалу самовизначення ця проблема досліджується опосередковано. Так, найбільш часто в науковій літературі відзначають взаємозв'язок креативності з соціальною екстраверсію й інтроверсію [13], незалежністю в судженнях, самоповагою, перевагою складних завдань, внутрішньою мотивацією [4]. Також визначено, що високий рівень розвитку рефлексивності пов'язаний 3 високим ступенем усвідомленості компонентів власної креативності та прагненням до їх розвитку. Досліджувані з низьким і середнім рівнем розвитку рефлексивності не виражають чіткого уявлення про власну креативність та ії «ідеальний» образ [10, с. 83].

О.В. Вдовіченко зміст поняття «ризик» розкриває через «нове», «ініціативу», «інтуїцію», «творчість». Так, ризик пов'язаний з творчістю -3 діяльністю, що характеризується неповторністю, оригінальністю, унікальністю. Іноді особистість, що ризикує, спочатку перед собою ставить вузько егоїстичне завдання - виразити себе в продуктах своєї творчості. Проте, чим більше вона висловлює, тим більше віддає свій продукт іншим людям. Можна припустити, що самовираження і ризик $є$ взаємодоповнюючими. Однак обидва можуть здійснюватися плідно тільки в тому разі, якщо предмет творчості матиме необхідну оригінальність. Відзначимо, що оригінальність, насамперед, виражається в творчому стилі особистості, багатстві ऑї індивідуальної натури. Але водночас оригінальність становить єдиний ключ, який відкриває наукові, естетичні та моральні цінності світу [1]. Рефлексія є «усвідомленням людиною самої себе, своїх реальних можливостей і потенційних ресурсів для саморозвитку, на основі яких можливе здійснення самовдосконалення», рефлексія розглядається як умова самозмінювання [2, c. 512-513].

Таким чином, на нашу думку, креативність, ризик, рефлексія виступають особистісними механізмами збагачення потенціалу самозмінювання.

Постановка завдання. Мета статті - визначити співвідношення потенціалу самозмінювання 3 креативністю і рефлексивністю як особистісними механізмами його розвитку.

Виклад основного матеріалу. Таким чином, згідно 3 наявними дослідженнями означеної теми, зовнішній світ не дає точних відомостей для прийняття людиною глобальних рішень чи форми поведінки в локальній конкретній ситуації, тому надзвичайно важливим стає власний вибір, його результат, вміння справлятися з невизначеністю, ставати творцем власного життєвого шляху як необхідної і достатньої умови для виживання в сучасному суспільстві, тому й відчуття необхідності змінюватися, готовність до цього, вміння спонукати себе до самозмінювання, рефлексувати цей процес і результат, підходити до нього нестандартно, творчо, надзвичайно важливі в житті людей [3, с. 135]. Відтак для дослідження зв'язку рефлексивності, креативності та самозмінювання особистості було обрано 
комплекс психодіагностичних інструментів. До нього ввійшли:

1. Опитувальник «Потенціал самозмінювання» (B.P. Манукян, I.P. Муртазіна, Н.В. Грішина), що містить шкали «потреба в самозмінюванні», «здатність до усвідомлених самозмінювань», «віра в можливість самозмінювання», «можливість самозмінювань», сума балів за якими дає інформацію щодо потенціалу самозмінювання особистості [9].

2. «Методика рівня вираженості та спрямованості рефлексії» (М. Грант) спрямована на виявлення співвідношення двох форм рефлексії - соціорефлексії та саморефлексії [5]

3. Застосування тесту «Методика діагностики особистісної креативності» (О.С. Тунік) дозволяє встановити такі параметри креативності: «допитливість», «уява», «складність», «схильність до ризику» та загальний рівень «особистісної креативності» [16].

У дослідженні взяли участь 100 осіб - студенти Д3 «Південноукраїнський національний педагогічний університет імені К.Д. Ушинського» (денного та заочного відділення факультету іноземних мов та соціально-гуманітарного факультету). На першому етапі здійснювався кількісний аналіз отриманих даних шляхом виявлення співвідношення, взаємозв'язків, специфіки групування обчислених змінних. Другий етап передбачав якісну обробку отриманих результатів.

Вивчення взаємозв'язків між усіма показниками здійснювалося за допомогою кореляційного аналізу (див. табл. 1).
За результатами кореляційного аналізу можна стверджувати додаткову зв'язаність між компонентами потенціалу самозмінювання, особистісною креативністю та рефлексією. Винятком є параметр «можливість самозмінювань» (МожСз), який від'ємно на 5\% значущості корелює з соціорефлексією та уявою. Цей, дивний на перший погляд, факт легко інтерпретувати з огляду на зміст шкали «можливість самозмінювань», яка включає прояви саме формально-динамічних характеристик людини, насамперед психічної ригідності, яка, на думку авторів методики [9], є значною перепоною у самозмінюванні, обмежуючи можливості змінювання себе, зв'язана 3 прагненням знаходитись в зоні комфорту, боязкістю новизни, конформізмом. Тож цілком природним $є$ незв'язаність (або обернений зв'язок) з параметрами рефлексивності та креативності. До речі, цей показник «можливість самозмінювань» (МожСз) виявляє від'ємні значущі зв'язки з іншими параметрами потенціалу самозмінювання.

Примітно, що віра в самозміни не зв'язана взагалі з рефлексією, але додатково корелює зі всіма показниками креативності. Як відомо, віра в себе, позитивне налаштування звільняє творчі сили людини, на противагу цьому, страх сковує та пригнічує. Т. Келлі та Д. Келлі [6] зауважують переплетеність віри в себе, в змогу самозмін, трансформацій взагалі та творчих можливостей людини, зазначаючи, що креативна впевненість виходить 3 серця, а всередині кожного 3 нас $\epsilon$ величезний творчий потенціал, актуалізація якого ймовірна в будь-який момент життя. Адже саме креативність О.В. Морозов [11] взагалі розглядав

Таблиця 1

Значущі коефіціснти кореляції між параметрами потенціалу самозмінювання, креативності та рефлексії

\begin{tabular}{|c|c|c|c|c|c|c|}
\hline & \multicolumn{5}{|c|}{ Компоненти потенціалу самозмінювання } \\
\hline & & ПотрС3 & ЗдУсвСз & $\mathrm{BipBC}_{3}$ & МожС3 & ПцСз \\
\hline \multirow{7}{*}{ 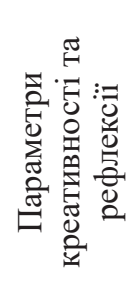 } & СамоРефл & $336 * *$ & $232 *$ & & & \\
\hline & СоціоРефл & $239 *$ & & & $-229 *$ & $266 * *$ \\
\hline & Допитл & $560 * *$ & $354 * *$ & $252 *$ & & $464 * *$ \\
\hline & Уява & $508 * *$ & $383 * *$ & $315 * *$ & $-229 *$ & $501 * *$ \\
\hline & Складн & $242 *$ & & $206^{*}$ & & $206^{*}$ \\
\hline & СхРиз & $345 * *$ & $260 * *$ & $307 * *$ & & $387 * *$ \\
\hline & Креат & $521 * *$ & $368 * *$ & $339 * *$ & & $492 * *$ \\
\hline
\end{tabular}

Примітки. Тут і далі: 1) показники потенціалу самозмінювання: «потреба в самозмінюванні» (ПотрСз), «здатність до усвідомлених самозмінювань» (ЗдУсвСз), «віра в можливість самозмінювання» (ВірВСз), «можливість самозмінювань» (МожСз). Сума балів за цими шкалами дає інформацію щодо підсумкового рівня потенціалу самозмінювання «ПцСз»; 2) показники рефлексії: «саморефлексія» (СамоРефл), соціорефлексія (СоціоРефл); 3) показники особистісної креативності: «допитливість» (Допитл), «уява» (Уява), «складність» (Складн), «схильність до ризику» (СхРиз) та загальний рівень «особистісної креативності» (Креат); 4) відмінність $\mathrm{p} \leq 0,05$ рівня значущості позначається «*», відмінність $\mathrm{p} \leq 0,01$ та $\mathrm{p} \leq 0,001$ рівнів значущості позначається «**»; 5) n=100 досліджуваних 
як основу інноваційності, спочатку розвивається креативність, а вже згодом здійснюється перетворення наявного досвіду керівника, змінювання особистості, ii самозмінювання в конструктивному ключі.

Найбільшу кількість корелятів виявлено у такого показника потенціалу самозмінювання, як «потреба в самозмінюванні» (ПотрСз) (значущі додатні зв'язки зі всіма показниками креативності та рефлексіі). Цей параметр потенціалу [9] належить до змістовних характеристик людини, особливостей її ціннісно-смислової сфери, мотиваційних спонукань і саме він демонструє рівень прагнення до самозмінювання.

Тож цілком зрозуміло, що потенціал самозмінювання людини тісно пов'язаний з ії креативністю, а потреба в самозмінюванні викристалізовується через залучення рефлексії, вектору іiі спрямованості як на себе, так і на соціум.

Подальший розгляд передбачав групування показників за допомогою кластерного аналізу (див. Рис. 1) з використанням методу міжгрупового зв'язку, що дозволяє отримати більш точні результати класифікації та дає змогу глибше зрозуміти через отриману кластерну структуру природу та ієрархічність взаємозв'язку показників, що аналізуються [12].

У результаті виявлення ієрархічної підпорядкованості встановлено, що утворилися декілька кластерів. В кластер самозмінювання на першому кроці агломерації ввійшли параметри потенціалу самозмінювання «потреба в самозмінюванні» та «здатність до усвідомлених самозмінювань» як найбільш близькі об'єкти, потім доєднався параметр «віра в можливість самозмінювання», а наступним кроком - «можливість самозмінювань».

Така підпорядкованість вказує на органічну етапність функціювання самозмінювання - від виникнення потреби через усвідомлення цієї потреби та власних сил у іiі реалізації до віри у власне самоздійснення та можливість його здійснити.

В основі кластеру «креативність» лежить допитливість та уява (перший крок агломераціі), потім приєднується «схильність до ризику», на наступному кроці - «складність». Завершується цей кластер соціорефлексією, яка є значущою для креативності, адже кожен наступний об'єкт приєднується до того кластера, до якого він $є$ найближчим.

Об'єднання кластерів креативності та самозмінювання пов'язано 3 саморефлексією, яка $\epsilon$ важливою гранню цих характеристик. Потенціал самозмінювання та рівень креативності особистості утворюють окремий кластер, що цілком очікувано, враховуючи їх тісний зв'язок. Важливо також те, що жоден $з$ цих показників не ввійшов до однойменних кластерів, а утворив окрему ієрархічну одиницю, яка доєдналась до кластерів «самозмінювання» та «креативність» та параметрів рефлексії, підкресливши важливість для

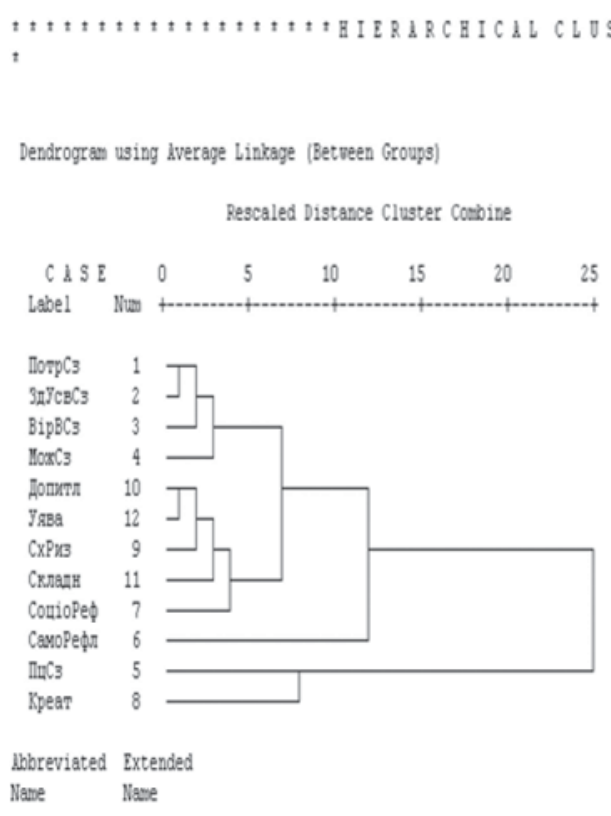

Рис. 1. Результати кластерного аналізу параметрів потенціалу самозмінювання, креативності та рефлексії 
загального рівня вираженості потенціалу самозмінювання всіх означених характеристик.

Отже, проведений кластерний аналіз дозволяє побудувати певну модель взаємозв'язку самозмінювання, креативності та рефлексії, позначивши їх підпорядкованість та значущість всіх для певного рівня вираженості потенціалу самозмінювання, що демонструє збагачення потенціалу самозмінювання через підвищення рефлексивності та креативності людини.

Висновки. За результатами теоретичного пошуку визначено обмеженість робіт з виявлення психологічних механізмів становлення потенціалу самозмінювання. Основна частина робіт торкається розробки дефініції самозмінювання, конструктів, що його представляє, діагностичних інструментів тощо. Практичні аспекти потребують врахування особистісних механізмів, детермінант, ресурсів розширення потенціалу самозмінювання.

Встановлено, що самозмінювання особистості знаходиться в прямій залежності від проявів ii креативності, а саме - розвиненості в особистості уяви, допитливості, зорієнтованості на пізнання складних явищ, вирішення важких завдань, схильності до ризику як здатності відважитись на щось нове, незвідане, а також загального рівня особистісної креативності.

Показано ієрархічну підпорядкованість самозмінювання, креативності та рефлексії та їх значущість для зростання потенціалу самозмінювання, що демонструє вектор збагачення потенціалу самозмінювання через підвищення рефлексивності та креативності людини.

Загалом за результатами дослідження можна припустити напрями подальшої практичної роботи щодо збагачення потенціалу самозмінювання через: розвиток первинних компонентів самозмінювання - потреби в самозмінюванні та здатності до усвідомлених самозмінювань; створення умов для розвитку всіх граней самозмінювання; розвиток креативності та залучення рефлексії, до того ж вектор іiї спрямованості має бути не тільки на себе, а й на соціум; наявність «живого» прикладу в оточенні з поєднанням означених характеристик важлива для розуміння змоги власних подібних трансформацій, важливо також враховувати детермінанти та ресурси розширення потенціалу самозмінювання тощо.

\section{Список літератури:}

1. Вдовиченко О.В. Роль риска в творческом процессе. Наука і освіта. 2007. № 4-5. С. 18-21.

2. Гаранина Ж.Г. Рефлексия как условие личностного саморазвития будущих специалистов. Современные тенденции в науке и образовании. Материалы Международной (заочной) научно-практической конференции. Под общ. ред. А.И. Вострецова. 2017. Изд-во: Научно-издательский центр «Мир науки». 2017. C. 512-516.

3. Гришина Н.В. «Самоизменения» личности: возможное и необходимое. Вестник Санкт-Петербургского университета. Психология и педагогика. 2018. Т. 8. Вып. 2. С. 126-138. DOI: https://doi.org/10.21638/11701/spbu16.2018.20.

4. Дружинин В.Н. Психология общих способностей. 3-е изд. Санкт-петербург : Питер, 2008.

5. Карпов А.В., Скитяева И.М. Психология метакогнитивных процессов личности. Москва : Изд-во «Институт психологии РАН», 2005. 352 с.

6. Келли Т., Келли Д. Креативная уверенность. Как высвободить и реализовать свои творческие силы. Москва : Азбука. 2015. 288 с.

7. Косырев В.Н. Самоизменение студента в деятельности овладения культурой учебного труда. Психологическая наука и образование. 2009. № 1. С. 82-89.

8. Манукян В.Р., Муртазина И.Р. Самоизменение: психологический статус и возможности измерения. Вестник Санкт-Петербургского университета. Психология. 2019. Т. 9. Вып. 4. С. 331-345. DOI: https://doi.org/10.21638/spbu16.2019.401.

9. Манукян В.Р., Муртазина И.Р., Гришина Н.В. Опросник для диагностики потенциала самоизменений личности. Консультативная психология и психотерапия. 2020. Т. 28. № 4. С. 35-58. DOI: https://doi.org/10.17759/cpp.2020280403.

10. Маркина Н.А., Галкина Т.В. Взаимосвязь рефлексии и креативности в образах «реального» и «идеального». Экспериментальная психология. 2011. Том 4. № 3. С. 74-85.

11. Морозов А.В. Креативность как основа инновационной активности и профессионализма современного руководителя. Психология в экономике и управлении. 2014. № 1. С. 125-129.

12. Наследов А.Д. Математические методы психологического исследования. Анализ и интерпретация данных. Учебное пособие. Санкт-Петербург : Речь, 2004. 392 с.

13. Петрайтите А.М. Связь интеллектуальных творческих способностей с экстраверсией - интроверсией. Вопросы психологии. 1981. № 6. С. 12-18. 
14. Розум С.И. Психология социализации и социальной адаптации человека. Санкт-Петербург : Речь, 2007. 365 с.

15. Титаренко Т.М. Вічна спрага життєвих змін (до психологічної природи вибору). Розвиток педагогічної і психологічної наук в Україні, 1992-2002: зб. наук. пр. до 10-річчя АПН України. Ч. 1 / АПН України. Харків : ОВС, 2002. С. 563-579.

16. Фетискин Н.П., Козлов В.В., Мануйлов Г.М. Социально-психологическая диагностика развития личности и малых групп. Москва : Изд-во Института Психотерапии, 2002. 490 с.

\section{Kazanzhy M.Y., Vdovichenko O.V. CREATIVITY AND REFLECTION AS PERSONAL MECHANISMS ENRICHING THE POTENTIAL OF SELF-CHANGE}

In modern conditions of life, with the predominance of uncertainty and constant transformations, the socially important quality of the average person is his ability to change, rapid and adequate response to today's challenges, self-transformation, the ability to implement it, which draws scientists to a deeper study of self-change. The analysis of existing works on this issue showed that despite the constant focus of scientific research of psychologists in the problem field of various aspects of self-change, only a limited number of works concerns the identification of psychological mechanisms of this process. In this regard, a very important task is to identify personal mechanisms for expanding the potential for self-change, the ratio of which allows you to identify features, assess the context and creatively change yourself, showing individuality and effectiveness in self-change.

To solve this problem, a set of psychodiagnostic tools was selected, which included: Questionnaire "Potential of self-change" (V.R. Manukyan, I.R. Murtazina, NV Grishin), "Methods of the level of expression and direction of reflection" (M. Grant) and "Methods of diagnosis of personal creativity" (O.E. Tunic). The sample included 100 people - students (because these categories of people according to the literature are prone to self-change).

According to the results of the study, the potential for human self-change is closely related to its creativity and the need for self-change crystallizes through the involvement of reflection, the vector of its focus on themselves and society. Cluster analysis showed the specifics of the relationship between self-change, creativity and reflection, indicating their subordination and significance of all for a certain level of expression of the potential for self-change, which demonstrates the enrichment of self-change potential by increasing human reflexivity and creativity. In general, the results of the study indicate the directions of further practical work on enriching the potential for self-change.

Key words: self-change, potential for self-change, creativity, reflexivity, psychological mechanism. 